\title{
Assessment of AMPK-Stimulated Cellular Long-Chain Fatty Acid and Glucose Uptake
}

Citation for published version (APA):

Luiken, J., Neumann, D., Glatz, J., Coumans, W., Chanda, D., \& Nabben, M. (2018). Assessment of AMPK-Stimulated Cellular Long-Chain Fatty Acid and Glucose Uptake. In D. Neumann, \& B. Viollet (Eds.), AMPK Methods and Protocols (Vol. 1732, pp. 343-361). Humana Press. Methods in Molecular Biology https://doi.org/10.1007/978-1-4939-7598-3_22

Document status and date:

Published: 01/01/2018

DOI:

10.1007/978-1-4939-7598-3_22

Document Version:

Publisher's PDF, also known as Version of record

Document license:

Taverne

Please check the document version of this publication:

- A submitted manuscript is the version of the article upon submission and before peer-review. There can be important differences between the submitted version and the official published version of record.

People interested in the research are advised to contact the author for the final version of the publication, or visit the DOI to the publisher's website.

- The final author version and the galley proof are versions of the publication after peer review.

- The final published version features the final layout of the paper including the volume, issue and page numbers.

Link to publication

\footnotetext{
General rights Owners
rights.

- You may freely distribute the URL identifying the publication in the public portal. please follow below link for the End User Agreement:

www.umlib.nl/taverne-license

Take down policy

If you believe that this document breaches copyright please contact us at:

repository@maastrichtuniversity.nl

providing details and we will investigate your claim.
}

Copyright and moral rights for the publications made accessible in the public portal are retained by the authors and/or other copyright owners and it is a condition of accessing publications that users recognise and abide by the legal requirements associated with these

- Users may download and print one copy of any publication from the public portal for the purpose of private study or research.

- You may not further distribute the material or use it for any profit-making activity or commercial gain

If the publication is distributed under the terms of Article $25 \mathrm{fa}$ of the Dutch Copyright Act, indicated by the "Taverne" license above, 


\title{
Assessment of AMPK-Stimulated Cellular Long-Chain Fatty Acid and Glucose Uptake
}

\author{
Joost J. F. P. Luiken, Dietbert Neumann, Jan F. C. Glatz, Will A. Coumans, \\ Dipanjan Chanda, and Miranda Nabben
}

\begin{abstract}
Here we describe an assay for simultaneous measurement of cellular uptake rates of long-chain fatty acids (LCFA) and glucose that can be applied to cells in suspension. The uptake assay includes the use of radiolabeled substrates at such concentrations and incubation periods that exact information is provided about unidirectional uptakes rates. Cellular uptake of both substrates is under regulation of AMPK. The underlying mechanism includes the translocation of LCFA and glucose transporters from intracellular membrane compartments to the cell surface, leading to an increase in substrate uptake. In this chapter, we explain the principles of the uptake assay before detailing the exact procedure. We also provide information of the specific LCFA and glucose transporters subject to AMPK-mediated subcellular translocation. Finally, we discuss the application of AMPK inhibitors and activators in combination with cellular substrate uptake assays.
\end{abstract}

Key words Long-chain fatty acid uptake, Glucose uptake, Initial uptake rate, AMPK inhibitors, AMPK stimuli, CD36 translocation, GLUT4 translocation

\section{Introduction}

For the majority of mammalian cell types, LCFA and glucose are the most important substrates for cellular energy production. But in order to serve as energy source, both substrates need to be taken up across the plasma membrane. In the remainder of this chapter, we focus on cardiomyocytes, but the general principles of the cellular uptake process are likely to apply to most other mammalian cell types, as has been proven for skeletal muscle cells, adipocytes, hepatocytes, enterocytes, etc. Notably, as observed in cardiomyocytes and skeletal muscle cells, the crossing of the plasma membrane presents the rate-limiting step in the cellular metabolism of both substrates [1-3]. Once inside the cells, both substrates can be readily oxidized according to the metabolic needs of the cells but also stored in times of plenty. Based on its lipophobic properties, 

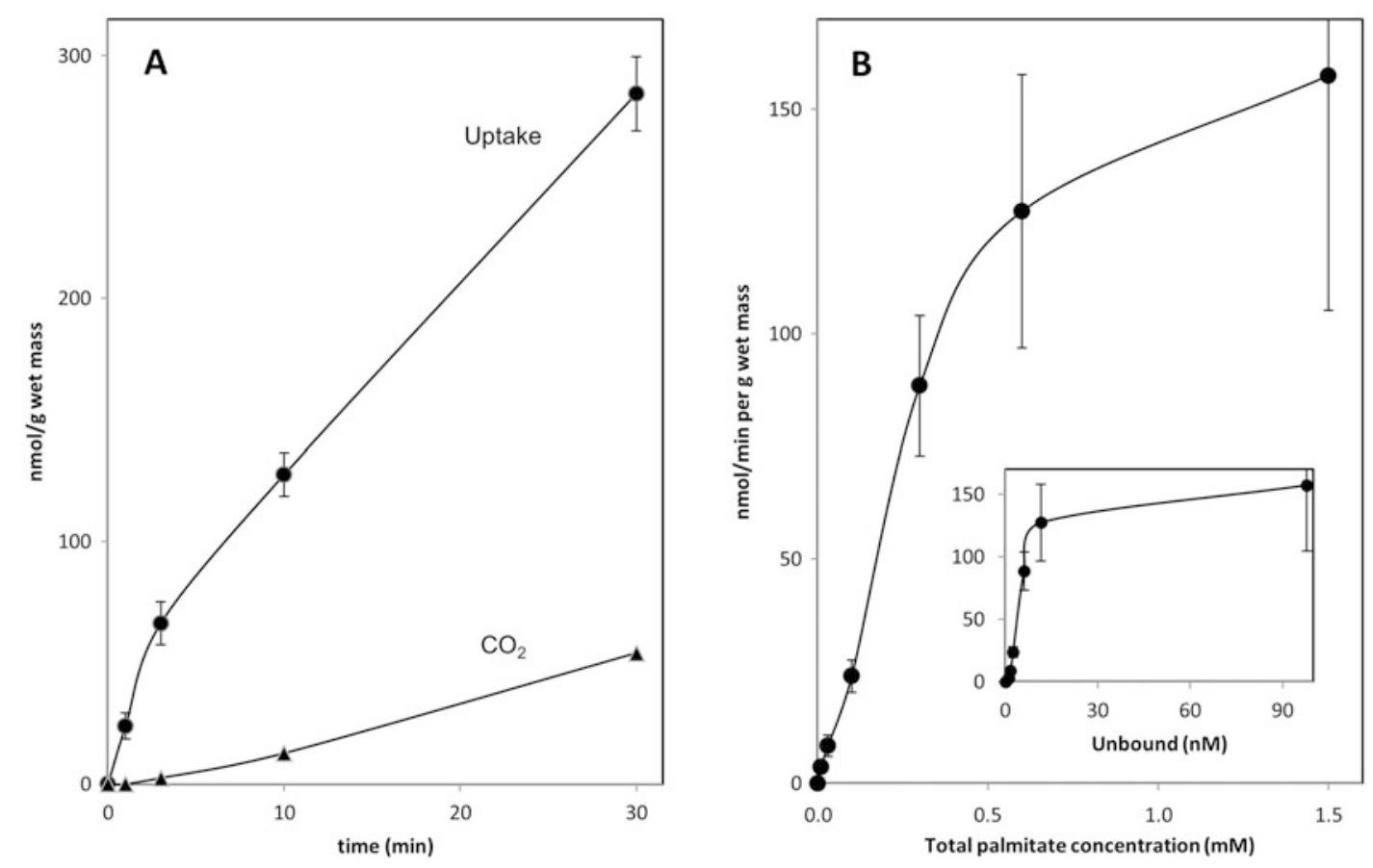

Fig. 1 Kinetics of palmitate uptake and utilization in rat cardiomyocytes. (a) Time course of palmitate uptake and utilization. Cardiomyocytes were incubated with palmitate bound to BSA at final concentrations of 90 and $300 \mu \mathrm{M}$, respectively (palmitate/BSA molar ratio 0.3 ), and analyzed at the indicated time points on cellular uptake of palmitate ( filled circle) and formation of $\mathrm{CO}_{2}$ ( filled triangle). (b) Palmitate uptake as function of the exogenous palmitate concentration. Cardiomyocytes were incubated with varying concentrations of palmitate bound to BSA (final BSA concentration $300 \mu \mathrm{M}$ ) resulting in palmitate/BSA molar ratios ranging from 0 to 5. Cellular uptake of palmitate was determined at $3 \mathrm{~min}$ after substrate addition. In the inset, palmitate uptake is plotted against the unbound palmitate concentration, which is calculated from the palmitate/BSA molar ratio [14]. This figure is modified from Ref. [8]

glucose does not readily cross the plasma membrane, and membrane transporters have long been recognized to mediate the bulk of glucose uptake [4]. These transporters are mainly members of the GLUT family: integral membrane proteins that contain 12 membrane-spanning helices. In contrast, due to their lipophilic properties, LCFA have been postulated to cross the plasma membrane solely via passive diffusion $[5,6]$. Only in the late 1980s of the previous century, transporters emerged as key mediators of bulk LCFA uptake (e.g., see [7]). The latter notion followed from several lines of kinetic evidence, including saturation of cellular LCFA uptake (Fig. 1), and sensitivity to competitive substrates and to inhibitors of protein-mediated membrane transport [2]. However, LCFA uptake also displays a non-saturable component, which at physiological LCFA concentrations contributes only modestly to the uptake process, but increases in relative contribution at exceedingly high nonphysiological concentrations [7]. The uptake procedure described below is carried out at low and physiological LCFA concentrations as measured in human plasma [8]. 


\subsection{Considerations of the Uptake Assay}

\subsubsection{Applicability}

\subsubsection{Radioactive} Tracers
This protocol of measurement of cellular substrate uptake is dedicated to primary cells in suspension and is suitable for investigation of the short-term regulation of substrate uptake. Working with primary cells in suspension has the advantage to prevent major cell loss accompanying their maintenance in culture. When one is interested in long-term regulation of substrate uptake, as exerted by transcription factors and subsequent de novo synthesis of substrate transporters, use of primary cells attached to laminin-coated wells is a more appropriate model of study. In that case, we advise to use a modified version of this uptake protocol [9]. On the other hand, cultured cells can be detached from their plates and undergo the uptake protocol as described below.

The most sensitive method to measure substrate uptake is via radioactive tracers. Uptake is measured as cell-associated radioactivity, which can be determined upon centrifugation and subsequent washing of the cells after a fixed time of incubation with the radioactive substrates. The most commonly used LCFA tracer is $\left[1-{ }^{14} \mathrm{C}\right]$ palmitate, but also $\left[{ }^{14} \mathrm{C}\right]$ or $\left[{ }^{3} \mathrm{H}\right]$ derivatives of oleate are often used, although these have the disadvantage of being considerably more expensive. The radiolabeled LCFA will be taken up into the cells mainly via LCFA transporters. Thereafter, they are intracellularly transported by small cytoplasmic fatty acidbinding proteins (FABP) to the cytoplasmic leaflet of the outer mitochondrial membrane for conversion into CoA esters by fatty acyl-CoA synthetase. This activation is needed for further metabolism, being oxidation within mitochondria, storage as triacylglycerols within lipid droplets and/or conversion into various other lipid species [3]. Depending on cell type and metabolic state, a variable portion of the fatty acyl-CoA will be destined for $\beta$-oxidation. Importantly, palmitate uptake needs to be measured during the initial uptake phase, when substrate uptake kinetics proceeds linear with time. Namely, beyond the initial uptake phase, efflux of the ${ }^{14} \mathrm{C}$-label will gradually increase as a result of equilibration of $\left[1-{ }^{14} \mathrm{C}\right]$ palmitate with the endogenous non-labeled palmitate pools [8]. Hence, during the initial uptake phase, measurement of uptake provides unbiased information on unidirectional influx of palmitate. Another reason for a rapid measurement of palmitate uptake relates to a progressive loss of ${ }^{14} \mathrm{C}$-label due to $\beta$-oxidation. Specifically using $\left[1-{ }^{14} \mathrm{C}\right]$ palmitate, the ${ }^{14} \mathrm{C}$-label at the $\mathrm{Cl}$ position will already disappear within the first round of $\beta$-oxidation, yielding a radioactive acetyl-CoA and a non-labeled myristoyl-CoA, of which the latter can no longer be traced. The radiolabeled acetylCoA subsequently enters the TCA cycle leading to ${ }^{14} \mathrm{CO}_{2}$ production. This $\mathrm{CO}_{2}$ diffuses away from the cells and the liquid medium into the gas phase. Hence, the portion of ${ }^{14} \mathrm{CO}_{2}$ produced from $\left[1-{ }^{14} \mathrm{C}\right]$ palmitate escapes the radioactive detection and leads to underestimation of the uptake rates. In metabolically active primary 


\subsubsection{LCFA-Albumin Ratios}

cardiomyocytes, this initial uptake phase amounts to 3-5 min after addition of the radiolabeled substrates (Fig. la) [8]. In most cardiac cell lines, the initial uptake rate is lower compared to primary cardiomyocytes and in the linear phase for up to $30 \mathrm{~min}[9,10]$.

To obtain information about cellular glucose uptake, non-metabolizable glucose analogs such as radiolabeled 2 -deoxyglucose (2-deoxy-D- $\left[{ }^{3} \mathrm{H}\right]$ glucose) are often applied, so that glucose uptake can be assessed independently of metabolism. Glucose and 2-deoxyglucose display similar uptake kinetics in cardiomyocytes (Luiken, unpublished). Whereas glucose is mostly used in uptake studies at physiological millimolar concentrations, it is advisable to use 2-deoxyglucose at submillimolar concentrations in order to minimize undesirable accumulation of 2-deoxyglucose-6-phosphate. The use of non-metabolizable analogs would also be advantageous for LCFA uptake studies. Yet, non-metabolizable LCFA analogs as 2-bromopalmitate [11] display much slower uptake rates due to the bulky bromo group and therefore do not reflect their naturally occurring counterparts. For the same reason, also iodo-fatty acids would display nonphysiologically low uptake rates. These iodo-fatty acids (e.g., 15-(p-iodophenyl)3(R,S)-methylpentadecanoic acid) are, however, suitable for PET imaging of myocardial metabolism [12].

Another complication with respect to measuring LCFA uptake is that this substrate is virtually insoluble in aqueous solutions [13]. In the mammalian circulation, LCFA are almost completely bound to albumin. In most cellular systems, high-affinity albumin binding sites have been found, which brings the LCFA-albumin complex in close proximity to the plasma membrane. Subsequently, the LCFA gain access to their membrane transporters. Hence, the cellular uptake of LCFA from the LCFA-albumin complex is an entire protein-mediated process. Conversely, dissolving radiolabeled LCFA in lipophilic solvents, such as DMSO, would lead to the partitioning of LCFA into the outer plasma membrane monolayer rather than being taken up by a physiological process involving membrane-binding proteins. Albumin has $6-8$ binding sites for LCFA. When palmitate will be mixed with albumin at ratios exceeding $8: 1$, palmitate micelles will be formed. Such micelles will readily incorporate into membranes so that nonphysiologically high uptake rates will be recorded. An important point of consideration is that palmitate is taken up as a function of the "free," i.e., nonalbumin-bound palmitate concentration and not the total palmitate concentration [8]. At least in media with albumin concentrations $>4 \mu \mathrm{M}$, the free palmitate concentration is entirely governed by the palmitate-albumin ratio [14]. Therefore in studies on fatty acid uptake regulation, the respective Materials and Methods sections (describing the uptake assay) should detail not only the total LCFA concentration but also the LCFA-albumin ratio. The physiological 


\subsubsection{Stop Procedures}

\subsubsection{Limitations}

\subsection{Regulation of Cellular Substrate Uptake by AMPK}

LCFA-albumin ratio roughly varies between 0.3 and 3 . Of further note, possible changes in LCFA uptake would be most sensitively detected at palmitate-albumin ratios well below the ratio at which the rate is half of $V_{\max }$, thus reflecting an apparent $K_{\mathrm{m}}$ (in analogy to Michaelis-Menten kinetics of enzyme reactions). As an example, in cardiomyocytes, palmitate-albumin ratios should be used below a ratio of 1.45 , which amounts to the apparent $K_{\mathrm{m}}$ of palmitate uptake in this cell type (Fig. 1b) [8].

Several stop procedures have been applied to terminate the uptake process, for instance, centrifugation of the cells through a layer of silicon oil [5]. This latter stop protocol can be applied to primary hepatocytes but is not suited for every cell type. For studies with cardiomyocytes, we have adopted a stop procedure from Sorrentino et al. [7]. This method brings together three different means contributing to stop radiolabeled substrate uptake: (1) dilution with excess cold substrate, $(2)$ removal of LCFA that are loosely attached to the outer leaflet of the plasma membrane (but have not been taken up) by inclusion of albumin in the stop buffer, and (3) addition of phloretin, a nonselective inhibitor of carrier-mediated membrane transport processes [15].

The substrate uptake rates to be calculated from these single-cell suspensions will definitely differ from the in vivo uptake rates, because the cells are incubated in the absence of blood-delivered hormonal and any mechanical stimuli. In primary culture, cardiomyocytes are not stimulated to contract and, at the most, will display some irregular spontaneous contractions. But these occasional contractions do not compare with the metabolic demands of the in vivo contractions. Hence, in vitro uptake rates are expected to be at least a magnitude lower. But nonetheless, single-cell suspensions offer the opportunity to investigate the kinetics and influence of stimulating/inhibiting agents in multiple parallel incubations.

The described protocol of cellular substrate uptake is designed for cells in suspension, which can be maintained in viable shape for periods up to $2 \mathrm{~h}$. Hence only short-term regulation of substrate uptake by AMPK needs to be taken into account. Theoretically these would include posttranslational modification (e.g., phosphorylation) of substrate transporters or, alternatively, translocation of substrate transporters from intracellular stores to the plasma membrane. In particular, there is a wealth of evidence that AMPK modulates substrate uptake through the translocation of substrate transporters $[3,16,17]$.

With respect to glucose uptake, mostly GLUT1 and GLUT4 have been investigated in relation to AMPK. Whereas AMPK regulation of GLUTI has been reported to occur via direct activation at 
the plasma membrane in clone-9 cells [18], GLUTl activity in muscle cells is generally regarded as non-inducible, involved in merely basal glucose uptake [19]. On the other hand, there is ample evidence that GLUT4 translocation is the main mechanism by which AMPK regulates changes in glucose uptake [20]. In case of LCFA uptake, a number of structurally unrelated proteins have been proposed to facilitate LCFA uptake. These proteins include the peripheral membrane protein FABPpm, the channel-forming family of the FATPs, and the scavenger receptor CD36, also referred to as SR-B2, supposedly acting as a flippase [3]. Although FABPpm, FATP1, and FATP4, but not FATP6, appear to translocate to the cell surface upon AMPK activation in skeletal muscle cells [21], this has not been reproduced in cardiomyocytes [22]. It is now well established that regulation of LCFA transport by cardiac AMPK relies entirely on the translocation of CD36 to the cell surface, with a very similar molecular mechanism to that of GLUT4. Of note, the same upstream and downstream signaling components appear to be involved, thereby further reinforcing the similarity of both translocation processes. The upstream and downstream mechanisms involved in AMPK-mediated GLUT4 translocation have been intensively studied (e.g., see Ref. [20]). In short, upstream of AMPK, the kinases LKBI and CaMKK- $\beta$ have been implicated, dependent on the cell type (LKBI in the heart and CaMKK- $\beta$ in skeletal muscle). Downstream of AMPK, AS160 is the most important AMPK target leading to GLUT4 translocation via de-inhibition of specific Rab proteins [23]. Remarkably, AMPKstimulated CD36 translocation in the heart and muscle shares the same upstream and downstream signaling components as AMPKstimulated GLUT4 translocation, including LKBI, CaMKK- $\beta$, and AS160 [24-26]. Hence the AMPK signaling pathway similarly regulates LCFA uptake and glucose uptake.

\section{Materials}

\subsection{Equipment}

2.2 Cells
1. Shaking water bath (including temperature control and holders for 20-mL vials).

2. Magnetic stirrer.

3. Gas phase system of $95 \% \mathrm{O}_{2} / 5 \% \mathrm{CO}_{2}$.

4. $\mathrm{N}_{2}$ gas.

5. Liquid scintillation counter ( $\beta$-counter).

6. Glass $\beta$-counter vials.

7. Cell suspensions can be obtained as primary cells upon isolation from rodent organs (e.g., heart) or can be derived from cell cultures upon dis-attachment from the culture wells. 


\subsection{Uptake Assay}

1. Ethanol.

2. DMSO.

3. $\mathrm{KOH}: 1 \mathrm{M} \mathrm{KOH}$.

4. $\mathrm{CaCl}_{2}: 100 \mathrm{mM} \mathrm{CaCl}_{2}$.

5. Bovine serum albumin (BSA)-Fraction V (fatty acid-free).

6. Palmitic acid.

7. $\left[1-{ }^{14} \mathrm{C}\right]$ palmitate.

8. 2-Deoxyglucose/2-deoxy-D- $\left[{ }^{3} \mathrm{H}\right]$ glucose mix: $10 \mathrm{mM}$ 2 -deoxyglucose and $2.2 \mu \mathrm{Ci} 2$-deoxy-D- $\left[{ }^{3} \mathrm{H}\right]$ glucose.

9. AMPK activators and/or inhibitors.

10. OPTI-FLUOR liquid scintillation cocktail. Solutions to Be Prepared in Advance

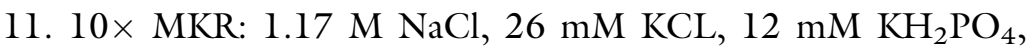
$12 \mathrm{mM} \mathrm{MgSO}_{4}, 100 \mathrm{mM} \mathrm{NaHCO}_{3}$, and $100 \mathrm{mM}$ HEPES, $\mathrm{pH}$ 7.55. Use a $1 \mathrm{~L}$ glass cylinder or a glass beaker. Weigh the indicated amount of the following chemicals: $68.36 \mathrm{~g}$ of $\mathrm{NaCl}$, $1.94 \mathrm{~g}$ of KCl, $1.63 \mathrm{~g}$ of $\mathrm{KH}_{2} \mathrm{PO}_{4}, 2.96 \mathrm{~g}$ of $\mathrm{MgSO}_{4} \cdot 7 \mathrm{H}_{2} \mathrm{O}$, $8.4 \mathrm{~g}$ of $\mathrm{NaHCO}_{3}$, and $23.83 \mathrm{~g}$ of HEPES. Add distilled $\mathrm{H}_{2} \mathrm{O}$ to a volume of $800 \mathrm{~mL}$. Mix and adjust $\mathrm{pH}$ to 7.55 with $1 \mathrm{M}$ $\mathrm{NaOH}$. Make up to $1000 \mathrm{~mL}$ with distilled $\mathrm{H}_{2} \mathrm{O}$ and store at $4{ }^{\circ} \mathrm{C}$. This stock solution should be diluted in later steps to the indicated dilutions.

12. Stock $\left[1-{ }^{14} \mathrm{C}\right]$ palmitate label: $1.8 \mathrm{mM}$ palmitate complexed to $0.3 \mathrm{mM}(\triangleq 2.0 \% \mathrm{w} / \mathrm{v}) \mathrm{BSA}, 17.4 \mu \mathrm{M}\left[1{ }^{-14} \mathrm{C}\right]$ palmitate, and $1 \mathrm{mM} \mathrm{CaCl}$ in $1 \times \mathrm{MKR}$. Prepare pre-warmed BSA solution in a $100 \mathrm{~mL}$ glass cylinder, by dissolving $1.0 \mathrm{~g}$ of BSA in $40 \mathrm{~mL}$ of $1,25 \times$ MKR. Place in a shaking water bath at $37{ }^{\circ} \mathrm{C}$ until further use $(100 \mathrm{rpm})$. Weigh $23.1 \mathrm{mg}$ of palmitic acid in a $100 \mathrm{~mL}$ glass cylinder, and dissolve in $9.5 \mathrm{~mL}$ of pure ethanol. Add $50 \mu \mathrm{Ci}$ of $\left[1-{ }^{14} \mathrm{C}\right]$ palmitate (see Note 1 ), and mix thoroughly. Use a $10 \mathrm{~mL}$ glass cylinder to prepare $10 \mathrm{~mL}$ of $\mathrm{KOH}$ solution by pipetting $135 \mu \mathrm{L}$ of $1 \mathrm{M} \mathrm{KOH}$ into $10 \mathrm{~mL}$ distilled $\mathrm{H}_{2} \mathrm{O}$. Add, drop by drop under constant stirring, the $10 \mathrm{~mL}$ of $\mathrm{KOH}$ solution to the $10 \mathrm{~mL}$ of palmitate-ethanol solution (see Note 2). Evaporate all ethanol at $45{ }^{\circ} \mathrm{C}$ (in water bath) under a constant stream of $\mathrm{N}_{2}$ gas until the odor of alcohol can no longer be detected and the volume is less than $8 \mathrm{~mL}$. Adjust the volume to $10 \mathrm{~mL}$ with distilled $\mathrm{H}_{2} \mathrm{O}$. Add this $10 \mathrm{~mL}$ $\mathrm{KOH}$-palmitate solution drop by drop with a glass pipette (see Note 3), under continuous gentle stirring ( see Note 2) to the pre-warmed BSA solution (total volume $50 \mathrm{~mL}$ ). Add $0.5 \mathrm{~mL}$ of $100 \mathrm{mM} \mathrm{CaCl} 2$. Transfer into glass centrifuge tubes, and spin down for $10 \mathrm{~min}$ at $3000 \times g$ at room temperature. 
Aliquot the supernatant into $2-5 \mathrm{~mL}$ portions in glass vials and store at $-20^{\circ} \mathrm{C}$.

\section{Solutions to Be Prepared Extemporaneously the Day of Experiment}

13. Uptake buffer: $1 \times \mathrm{MKR}, 1 \mathrm{mM} \mathrm{CaCl} 2$, and $0,45 \%(\mathrm{w} / \mathrm{v}) \mathrm{BSA}$. Take a $100 \mathrm{~mL}$ glass cylinder. Add $0.23 \mathrm{~g}$ of BSA, $49.5 \mathrm{~mL}$ of MKR buffer, and $0.5 \mathrm{~mL}$ of $100 \mathrm{mM} \mathrm{CaCl}$. Place uptake buffer in a water bath at $37^{\circ} \mathrm{C}$.

14. Day Label (for up to 20 incubations): $100 \mu \mathrm{M}\left[1^{-14} \mathrm{C}\right]$ palmitate, $100 \mu \mathrm{M}$ deoxy-glucose, and $3.3 \mu \mathrm{Ci} 2$-deoxy-D- $\left[{ }^{3} \mathrm{H}\right]$ glucose. Take a $10 \mathrm{~mL}$ glass vial, and add $9.34 \mathrm{~mL}$ of uptake buffer, $0.56 \mathrm{~mL}$ of Stock $\left[1{ }^{14} \mathrm{C}\right]$ palmitate label, and $100 \mu \mathrm{L}$ of $10 \mathrm{mM} 2$-deoxyglucose /2-deoxy-D- $\left[{ }^{3} \mathrm{H}\right]$ glucose mix. Place the vial in a water bath at $37^{\circ} \mathrm{C}$.

15. Stop solution (for $\sim 20$ incubations): $0.2 \mathrm{mM}$ phloretin and $0.1 \%(\mathrm{w} / \mathrm{v})$ BSA. Prepare phloretin solution by dissolving $21.8 \mathrm{mg}$ of phloretin in $400 \mu \mathrm{L}$ DMSO. Use a $500 \mathrm{~mL}$ glass cylinder, and add $400 \mathrm{~mL}$ of $\mathrm{l} \times \mathrm{MKR}$ buffer, $4.0 \mathrm{~mL}$ of $100 \mathrm{mM} \mathrm{CaCl} 2,0.40 \mathrm{~g}$ of BSA (Fraction V, essentially fatty acid-free), and the phloretin solution. For each condition, prepare a $15-\mathrm{mL}$ centrifugation tube with $8 \mathrm{~mL}$ Stop solution added. Place tubes on ice.

16. Working solutions of desired AMPK stimuli (see Note 4) and/or inhibitors (see Note 5).

\section{Methods}

1. Suspend cells in uptake buffer $(50,000-500,000$ cells $/ \mathrm{mL})$ (depending on metabolic activity of cells; see Notes 6 and 7), and distribute over $(20-\mathrm{mL})$ glass vials. Add $2 \mathrm{~mL}$ of cell suspension per vial.

2. Preincubate the cell suspension at $37{ }^{\circ} \mathrm{C}$ with a gas phase of $95 \% \mathrm{O}_{2} / 5 \% \mathrm{CO}_{2}$ with inhibitors of AMPK for $20 \mathrm{~min}$ in a water bath (shaking at $160 \mathrm{rpm}$ ).

3. Subsequently, add activators of AMPK, refill the gas phase, and incubate for another $30 \mathrm{~min}$ at $37^{\circ} \mathrm{C}$.

4. Start the uptake assay by adding $0.5 \mathrm{~mL}$ of Day Label to the cell suspension, and incubate for $5 \mathrm{~min}$ at $37^{\circ} \mathrm{C}$ in a water bath with a gas phase of $95 \% \mathrm{O}_{2} / 5 \% \mathrm{CO}_{2}$. Each cellular substrate uptake assay should include a "zero time control" to allow to correct for the background signal ( see Note 8).

5. After $5 \mathrm{~min}$, stop the assay, and transfer $2 \mathrm{~mL}$ of cell suspension from each incubation to centrifugation tubes with $8 \mathrm{~mL}$ of ice-cold Stop solution. 
6. Spin the cells down for $\leq 2 \mathrm{~min}$ at $4{ }^{\circ} \mathrm{C}$ ( see Note 9). Remove the supernatant and wash with $10 \mathrm{~mL}$ of ice-cold Stop solution. Repeat the centrifugation step.

7. Lyse the pellets in $0.5 \mathrm{~mL}$ of distilled $\mathrm{H}_{2} \mathrm{O}$, and transfer the lysates to $20 \mathrm{~mL}$ glass $\beta$-counter vials containing $5 \mathrm{~mL}$ of OPTI-FLUOR liquid scintillation cocktail. Do not forget to include a sample with a fixed volume (e.g., $20 \mu \mathrm{L}$ ) of Day Label for scintillation counting in order to allow for calculation of absolute uptake rates.

8. Vortex the samples, and measure the disintegration counts per minute at the $\beta$-counter using a combined ${ }^{3} \mathrm{H} /{ }^{14} \mathrm{C}$ counting protocol. Uptake values are expressed as nmol/(gwet mass * $\mathrm{min})$, after subtracting the background signal (see Note 8). A representative data set of a substrate uptake assay using AMPK activators is given in Table 1.

1. It is advised to purchase and use a radiolabeled palmitate product dissolved in ethanol, and not toluene, because toluene is extremely toxic to cells.

2. If precipitate is formed, discard the solution and start again.

3. Work as much as possible with glassware because (radiolabeled) palmitate binds non-specifically to plastic surfaces. In the uptake assay, this can lead to high background counts.

4. For selecting the appropriate AMPK activators to be used in the intended experiments, at least the following five items are relevant: (1) the cellular uptake process of interest, (2) the tissue of interest from which primary cells will be isolated, (3) the type of physiological process one aims to mimic or investigate, (4) the off-target actions of selected compound, and (5) the toxic effects of selected compound depending on the cell type.

An increasing number of pharmacological AMPK activators have been employed for the study of AMPK activation on cellular LCFA and glucose uptake. We provide here with some tips and consideration about the most commonly used compounds to investigate substrate uptake in muscle cells:

- Oligomycin: It is a very potent stimulator of glucose and LCFA uptake in primary cardiomyocytes and in cardiac cell lines in which the uptake of both substrates increases by $\sim$ twofold already within $15-30 \mathrm{~min}$ [16]. It is of note that the concentration of oligomycin tolerated by cells differs among cell types. In cardiomyocytes, oligomycin can be used at concentrations of up to $30 \mu \mathrm{M}$, but this 


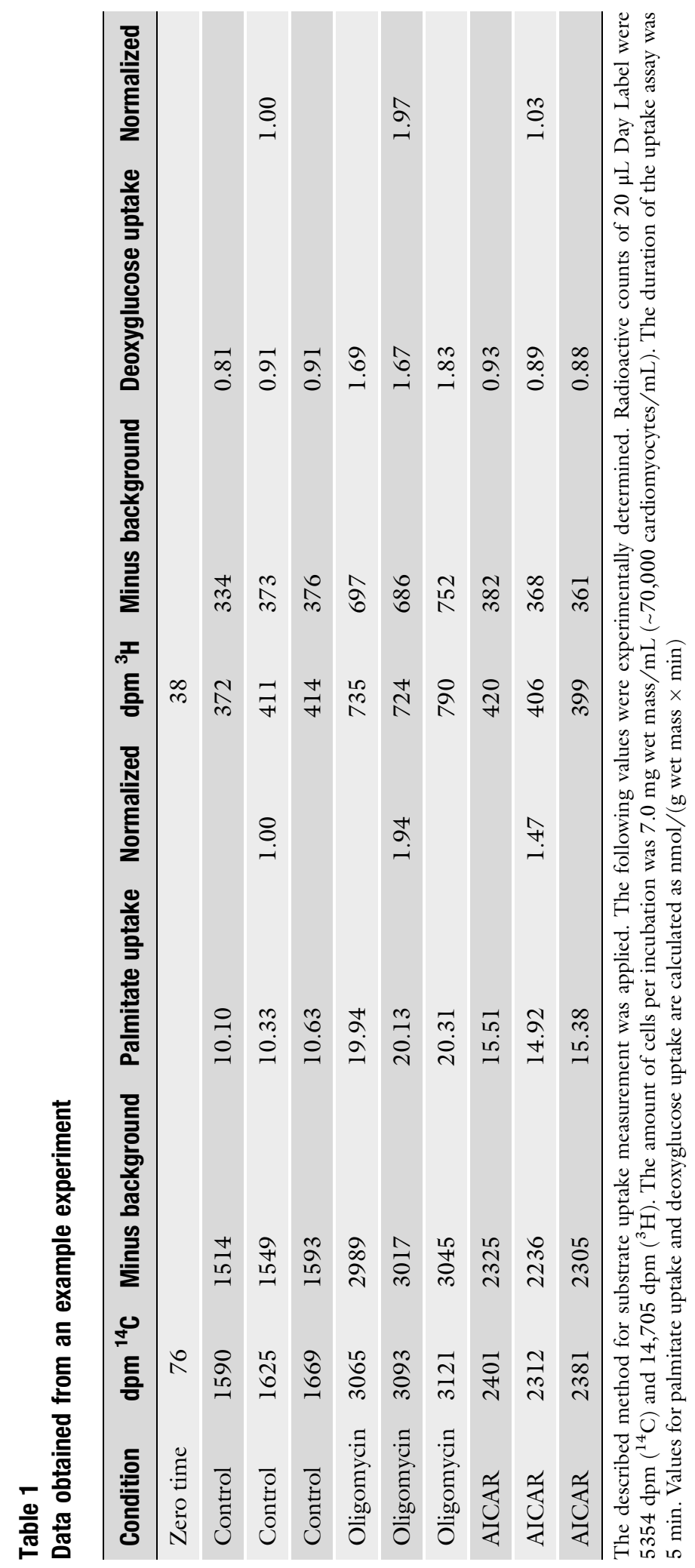


concentration is cytotoxic in cell lines, such as HL-1 cells, in which concentrations of up to $1 \mu \mathrm{M}$ are more advisable. Importantly, besides activation of AMPK [16], oligomycin also stimulates production of reactive oxygen species and subsequent activation of protein kinase-Dl, another crucial player in oligomycin-induced GLUT4 translocation and cellular glucose uptake [27].

- Mitochondrial inhibitors: Uncoupling agents (such as 2,4-dinitrophenol) and respiratory chain inhibitors (rotenone) stimulate cellular glucose uptake in adipocytes and myocytes [28, 29]. However, these agents cannot be used to study cellular LCFA uptake. Unlike glucose uptake, LCFA uptake across the plasma membrane is dependent on the cellular membrane potential [30], which is destroyed by these agents since their protonophore activity is not restricted to mitochondria $[28,31]$. The respiratory chain inhibitor rotenone potently impairs the oxidative metabolism of both substrates. Because uptake and subsequent metabolism are tightly coupled processes, the block in oxidative phosphorylation leads to feedback inhibition of the LCFA uptake process [8]. In contrast, the acceleration of glucose uptake upon rotenone-induced AMPK activation may be accommodated for by a concomitant acceleration in glycolysis so that all incoming glucose is efficiently phosphorylated and feedback inhibition will not occur. In case of specific interest in AMPK-stimulated glucose uptake, DNP and rotenone should preferably be used at low micromolar concentrations.

- AICAR: One point of concern with the use of AICAR is the increasing list of AMPK-independent actions of AICAR [32]. Nonetheless, AICAR has been used as activator of LCFA uptake in skeletal muscle [33] and glucose uptake in adipocytes [29] and skeletal muscle [34]. In cardiomyocytes, AICAR, at low millimolar concentrations, stimulates LCFA uptake by $~ 1.5$-fold in an AMPK-dependent fashion $[25,35]$, but this compound is not effective in stimulation of GLUT4 translocation and cellular glucose uptake (Fig. 2b) $[25,35,36]$. Thus it appears that the stimulation of cellular glucose uptake by AICAR is tissue-specific and should be taken into consideration when studying the effects of AMPK activation on substrate uptake.

- Metformin and phenformin: Although these antidiabetic drugs are known to activate AMPK at low millimolar concentrations $[37,38]$, they failed to increase GLUT4 or CD36 translocation or cellular uptake of LCFA and glucose within $30 \mathrm{~min}$ in cardiomyocytes [39] (Luiken, unpublished). However, metformin has been shown to stimulate 


\section{LCFA uptake}

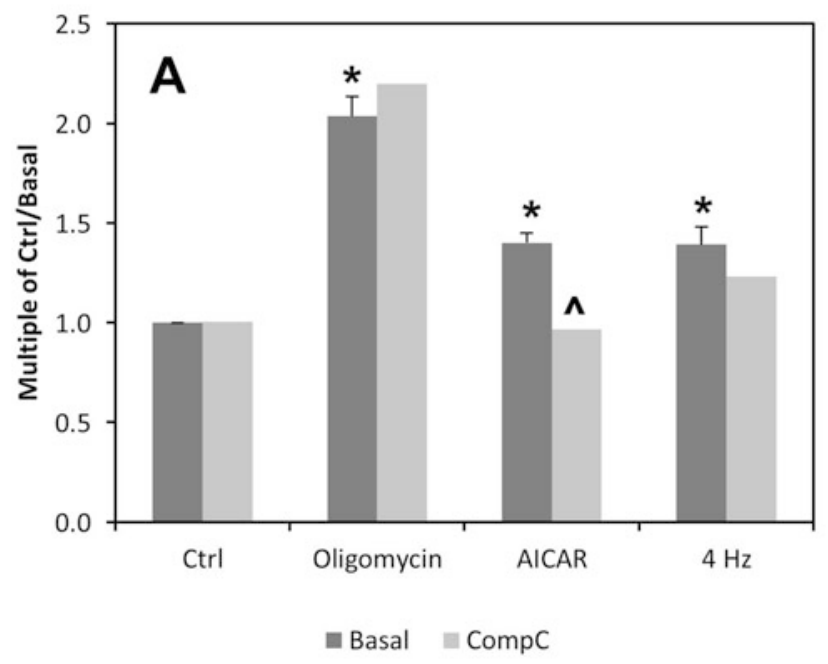

\section{Glucose uptake}

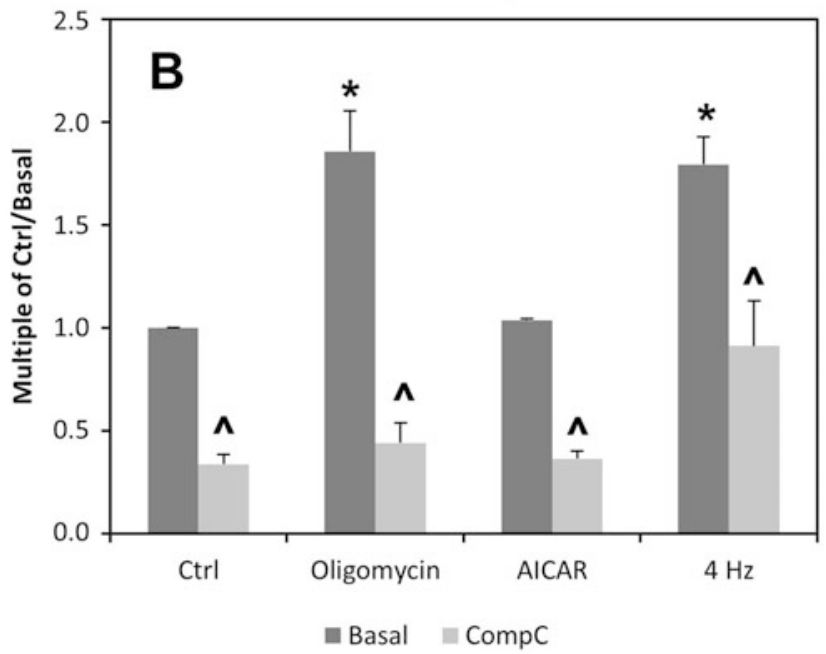

Fig. 2 Effects of Compound $C$ on substrate uptake into rat cardiomyocytes stimulated by various AMPK activators. Cell suspensions were incubated in absence or presence of $50 \mu \mathrm{M}$ Compound $\mathrm{C}$ for $30 \mathrm{~min}$, and subsequently for another 15 min without or with $5 \mu \mathrm{M}$ oligomycin or $1.5 \mathrm{mM}$ AICAR. Alternatively, electrostimulation was performed for $7 \mathrm{~min}$ at $4 \mathrm{~Hz}$. Then, radioactive substrates were added for measurement of (a) palmitate uptake or (b) deoxyglucose uptake during $5 \mathrm{~min}$. Data are means \pm S.E.M $(n=4-6)$. "Significantly different from myocytes without additions (Ctrl) $(p<0.05)$. ^Significantly different from corresponding incubations in the absence of Compound $\mathrm{C}$ (Basal) $(p<0.05)$

GLUT4 translocation in cardiomyocytes upon long-term $(18 \mathrm{~h})$ treatment, indicating reliance on synthesis of specific proteins. These proteins might be involved in the negative regulation of GLUT4 endocytosis [39]. 
- Small-molecule direct AMPK activators: A screen by the Abbott Laboratories of $>700,000$ compounds yielded a non-nucleoside thienopyridone, A-769662, as novel smallmolecule AMPK activator [40]. In skeletal muscle strips, it appeared ineffective on stimulation of glucose uptake [41]. In cardiomyocytes at concentrations between 30 and $300 \mu \mathrm{M}$, during $30 \mathrm{~min}$, it also failed to stimulate AMPKThr172 phosphorylation or LCFA and glucose uptake (Habets and Luiken, unpublished). Compared with $\beta 1$-containing heterotrimers, $\beta 2$-containing AMPK isoforms are less efficiently activated by A-769662 [42]. Given that muscle tissues mainly express the AMPK $\beta 2$ subunit isoform, A-769662 may be a less favorable option for studying the role of AMPK in the heart and skeletal muscle.

More recently, another small-molecule AMPK activator, 991 (also known as ex229), has been described [41]. Although it shares the same binding site on AMPK as A-769662, it showed a $\sim$ tenfold greater potency to activate AMPK [43]. Interestingly, 991 activates both AMPK $\beta 1$ - and $\beta 2$-containing complexes and efficiently stimulates glucose uptake into skeletal muscle at $100 \mu \mathrm{M}$ for $60 \mathrm{~min}$ [41]. Further studies are required to investigate whether this compound is a suitable tool to study substrate uptake in cardiac cells.

- Leptin: This hormone is a physiological AMPK activator and stimulates CD36 translocation in an AMPK-dependent manner at $10 \mu \mathrm{g} / \mathrm{mL}$ for $15-60 \mathrm{~min}$, as well as LCFA uptake in skeletal muscle incubations and cardiomyocytes [44]. With respect to glucose uptake, 20 min leptin was ineffective in stimulating glucose uptake in HL-1 cardiomyocytes [45]. In contrast, $30 \mathrm{~min}$ leptin stimulates GLUT4 translocation in C2C12 myotubes, which was dependent on ERK2 [46] and perhaps independent of AMPK. Hence, a pleiotropy of stimulatory actions on intracellular signaling cascades makes leptin less suited as a tool to study AMPK-specific regulation of substrate uptake.

5. Genetic approaches would be the preferable manner to investigate the involvement of AMPK in substrate uptake. An excellent option would be to use primary cells from tissues derived from AMPK knockout mouse models for assessment of cellular substrate uptake. But since at least two isoforms of the catalytic $\alpha$ and regulatory $\beta$ subunits are expressed in mammals, one needs double-knockout mouse models for these subunits to provide full proof for the involvement of AMPK. But in case that one is only interested in the role of AMPK in a specific tissue, a single-knockout mouse will suffice, when the respective tissue only expresses one isoform. For example, in muscle 
tissues, AMPK $\alpha 2$ knockout mice would be suitable, given that the $\alpha \mathrm{l}$ subunit is only marginally expressed in muscles. Furthermore, the muscle-specific kinase-dead AMPK $\alpha 2$ overexpressing mouse [47] provides a very suitable model for the role of AMPK in muscles. A second option would be to silence AMPK in cell lines, e.g., by siRNA approach or CRISPR/Cas9 (see Chapter 11). However, when AMPK mouse models or silencing methodologies are not available, one can consider a pharmacological approach and use small-molecule AMPK inhibitors. Below is a list of compounds previously used in substrate uptake studies:

- 5-Iodotubercidin: 5-Iodotubercidin is not a direct AMPK inhibitor but blocks the formation of AMP from adenosine via inhibition of adenosine kinase [48]. Treatment with 5-iodotubercidin for $10 \mu \mathrm{M}$ at 15-30 min blocks AICARinduced LCFA uptake into cardiomyocytes [16] and glucose uptake into clone-9 cells [18] and muscle strips [49], in agreement with its ability to inhibit ZMP formation. In contrast, 5-iodotubercidin does not alter contraction and oligomycin-stimulated LCFA uptake into cardiomyocytes [16], which is readily explained by the fact that AMP formation due to stress or increased energy demands is derived from ATP utilization and not from AMP synthesis. Hence, 5 -iodotubercidin is of limited use to study AMPK actions.

- Adenine 9- $\beta$-D-arabinofuranoside (Ara-A): This AMP ana$\log$ decreases AMPK activity in vitro [50]. Ara-A is used in concentrations of $2-3 \mathrm{mM}$ for $15-30 \mathrm{~min}$ and entirely inhibits AICAR-induced glucose uptake into muscle strips [49]. It also inhibits stimulation of GLUT4 translocation and glucose uptake in neonatal cardiomyocytes by respiratory chain inhibition using sodium azide $\left(\mathrm{NaN}_{3}\right)$. Furthermore, Ara-A inhibits AICAR-stimulated LCFA uptake into primary cardiomyocytes [35] and also leptin-stimulated CD36 translocation and LCFA uptake into skeletal muscle and primary cardiomyocytes [44]. Hence, as AMPK inhibitor, Ara-A has a broader applicability than 5-iodotubercidin in studying AMPK-related actions but has also numerous other inhibitory effects, such as inhibition of adenylyl cyclase [51].

- Compound C: As selected from a high-throughput in vitro kinase assay out of $>10.000$ compounds, Compound C appeared a potent reversible AMPK antagonist via competition with ATP [37]. Compound C is mostly used in concentrations of $10-50 \mu \mathrm{M}$ and has been shown to inhibit AICAR-induced GLUT4 translocation [52] and AICARstimulated glucose uptake [53]. We have used Compound $\mathrm{C}(50 \mu \mathrm{M})$ to study AMPK-mediated LCFA and glucose 
uptake into primary cardiomyocytes. AICAR-stimulated LCFA uptake was entirely inhibited, whereas contraction and oligomycin-stimulated LCFA uptake were not significantly altered (Fig. 2a). This inhibition pattern does not match with the presumed direct action of Compound C on AMPK. Furthermore, interpretation of the effects of Compound $\mathrm{C}$ on AMPK-stimulated glucose uptake was complicated by a large effect of this inhibitor on basal glucose uptake (Fig. 2b), in agreement with Merlin et al. [53]. Please note that AICAR does not stimulate glucose uptake into rodent cardiomyocytes (Fig. 2b). Finally, the list of off-target actions of Compound $\mathrm{C}$ on other kinases, such as ERK8 and $\mathrm{MNKl}$, is growing [54]. As described in Chapter 12, there are serious doubts about the specificity of Compound $\mathrm{C}$ and whether it is a useful tool for studying AMPK.

- STO-609: STO-609 does not inhibit AMPK directly but rather blocks upstream activation. Specifically, STO-609 is an antagonist of $\mathrm{Ca}^{2+} /$ calmodulin-dependent kinase kinase (CaMKK) [55]. Together with liver kinase Bl (LKBl) and transforming growth factor beta-activated kinase 1 (TAKl) [56], CaMKK- $\beta$ is one of the several kinases able to directly activate AMPK. Hence, STO-609 is of no use to study activation of AMPK by LKBI and TAKl. Given that most inflammatory stimuli act via TAKl and given that $\mathrm{LKBl}$ is the major upstream activator of AMPK in several tissues, including the heart [25], STO-609 is often of limited use in AMPK research. We observed that STO-609 (5 $\mu \mathrm{M}$; $20 \mathrm{~min}$ ) does not block LCFA and glucose uptake stimulated by oligomycin or AICAR [35].

But still, STO-609 may be a suitable tool to connect $\mathrm{Ca}^{2+}$ signaling to AMPK signaling. In skeletal muscle, the $\mathrm{Ca}^{2+}$ signaling activator caffeine stimulates AMPK $\alpha 2$ activation, and also LCFA and glucose uptake. Moreover, LCFA and glucose uptake stimulated by contraction or caffeine is largely blocked by STO-609 indicating an important role of CaMKK- $\beta$ in AMPK regulation of substrate uptake in contracting muscle [24]. In contrast STO-609 did not inhibit contraction-stimulated LCFA and glucose uptake into primary cardiomyocytes, pinpointing to a less prominent role of $\mathrm{Ca}^{2+}$ signaling in contraction-regulated metabolism in the heart [35].

6. The isolation procedure raises cellular stress levels, and primary cells should preferably undergo a recovery period of $\sim 90 \mathrm{~min}$ at room temperature after their isolation to allow the metabolic rate to decrease to low "basal" levels. In case of cultured cells, a $\sim 60 \mathrm{~min}$ recovery period is recommended after the 
dis-attachment from the plates with a low trypsin concentration $(\leq 0.05 \%)$ to minimize damage to exposed substrate transporters at the cell surface.

7. Most primary cells can be regarded as metabolically active cells, especially since isolation procedures have been optimized for many years. When these cells are immediately used for substrate uptake assays, their metabolic activity will be highest, likely resulting in relatively high substrate uptake rates. Culturing of primary cells leads to a marked decline in metabolic activity depending on the duration and culturing conditions. Upon their dis-attachment from the culture wells, it is therefore recommended to use higher cell densities in the uptake assay, compared to their freshly used counterparts. Lowest metabolic activity is displayed by the cell lines and likely dependent on the number of passages. Therefore, relatively high cell densities should be used in order to obtain accurately detectable uptake values. Overall, it is recommended to perform a pilot measurement of substrate uptake as function of the cell density.

8. Correction for background signal: At least one incubation per experiment should serve as "zero time control" $(t=0)$. In this case, the cell suspension $(1.6 \mathrm{~mL})$ should be transferred to the Stop solution prior to addition of the Day Label $(0.4 \mathrm{~mL})$. The remainder of the procedure is similar as described for the other incubations. When performing the calculation of uptake rates, the counts of this "zero time control" should be subtracted from the radioactive counts of each incubation.

9. The centrifugation speed is dependent on the size of the cells (e.g., primary cardiomyocytes are pelleted at $25 \times g$; several cell lines require centrifugation speeds of $\sim 1000 \times \mathfrak{g}$ ).

\section{References}

1. Shulman GI (2000) Cellular mechanisms of insulin resistance. J Clin Invest 106 (2):171-176. https://doi.org/10.1172/ JCI10583

2. Luiken JJ, Schaap FG, van Nieuwenhoven FA, van der Vusse GJ, Bonen A, Glatz JF (1999) Cellular fatty acid transport in heart and skeletal muscle as facilitated by proteins. Lipids 34 (Suppl):S169-S175

3. Glatz JF, Luiken JJ, Bonen A (2010) Membrane fatty acid transporters as regulators of lipid metabolism: implications for metabolic disease. Physiol Rev 90(1):367-417. https:// doi.org/10.1152/physrev.00003.2009

4. Mueckler M (1994) Facilitative glucose transporters. Eur J Biochem 219(3):713-725
5. Rose H, Hennecke T, Kammermeier H (1990) Sarcolemmal fatty acid transfer in isolated cardiomyocytes governed by albumin $/ \mathrm{mem}$ brane-lipid partition. J Mol Cell Cardiol 22 (8):883-892

6. Hamilton JA, Johnson RA, Corkey B, Kamp F (2001) Fatty acid transport: the diffusion mechanism in model and biological membranes. J Mol Neurosci 16(2-3):99-108.; discussion 151-157. https://doi.org/10.1385/ JMN:16:2-3:99

7. Sorrentino D, Stump D, Potter BJ, Robinson RB, White R, Kiang CL, Berk PD (1988) Oleate uptake by cardiac myocytes is carrier mediated and involves a $40-\mathrm{kD}$ plasma membrane fatty acid binding protein similar to that in liver, adipose tissue, and gut. J Clin Invest 82 
(3):928-935. https://doi.org/10.1172/ JCI1 13700

8. Luiken JJ, van Nieuwenhoven FA, America G, van der Vusse GJ, Glatz JF (1997) Uptake and metabolism of palmitate by isolated cardiac myocytes from adult rats: involvement of sarcolemmal proteins. J Lipid Res 38(4):745-758

9. Schwenk RW, Dirkx E, Coumans WA, Bonen A, Klip A, Glatz JF, Luiken JJ (2010) Requirement for distinct vesicle-associated membrane proteins in insulin- and AMP-activated protein kinase (AMPK)induced translocation of GLUT4 and CD36 in cultured cardiomyocytes. Diabetologia 53 (10):2209-2219. https://doi.org/10.1007/ s00125-010-1832-7

10. Van Nieuwenhoven FA, Luiken JJ, De Jong YF, Grimaldi PA, Van der Vusse GJ, Glatz JF (1998) Stable transfection of fatty acid translocase $(\mathrm{CD} 36)$ in a rat heart muscle cell line (H9c2). J Lipid Res 39(10):2039-2047

11. Oakes ND, Kjellstedt A, Forsberg GB, Clementz T, Camejo G, Furler SM, Kraegen EW, Olwegard-Halvarsson $M$, Jenkins AB, Ljung B (1999) Development and initial evaluation of a novel method for assessing tissuespecific plasma free fatty acid utilization in vivo using $(\mathrm{R})$-2-bromopalmitate tracer. J Lipid Res 40(6):1155-1169

12. Verberne HJ, Sloof GW, Beets AL, Murphy AM, van Eck-Smit BL, Knapp FF (2003) 125I-BMIPP and 18F-FDG uptake in a transgenic mouse model of stunned myocardium. Eur J Nucl Med Mol Imaging 30(3):431-439

13. Vorum H, Brodersen R, Kragh-Hansen U, Pedersen AO (1992) Solubility of long-chain fatty acids in phosphate buffer at $\mathrm{pH}$ 7.4. Biochim Biophys Acta 1126(2):135-142

14. Richieri GV, Ogata RT, Kleinfeld AM (1994) Equilibrium constants for the binding of fatty acids with fatty acid-binding proteins from adipocyte, intestine, heart, and liver measured with the fluorescent probe ADIFAB. J Biol Chem 269(39):23918-23930

15. Andersen BL, Tarpley HT, Regen DM (1978) Characterization of beta-hydroxybutyrate transport in rat erythrocytes and thymocytes. Biochim Biophys Acta 508(3):525-538

16. Luiken JJ, Coort SL, Willems J, Coumans WA, Bonen A, van der Vusse GJ, Glatz JF (2003) Contraction-induced fatty acid translocase/ CD36 translocation in rat cardiac myocytes is mediated through AMP-activated protein kinase signaling. Diabetes 52(7):1627-1634

17. Klip A, Schertzer JD, Bilan PJ, Thong F, Antonescu C (2009) Regulation of glucose transporter 4 traffic by energy deprivation from mitochondrial compromise. Acta Physiol (Oxf) 196(1):27-35. https://doi.org/10. $1111 /$ j.1748-1716.2009.01974.x

18. Abbud W, Habinowski S, Zhang JZ, Kendrew J, Elkairi FS, Kemp BE, Witters LA, Ismail-Beigi F (2000) Stimulation of AMP-activated protein kinase (AMPK) is associated with enhancement of Glutl-mediated glucose transport. Arch Biochem Biophys 380 (2):347-352. https://doi.org/10.1006/abbi. 2000.1935

19. Abel ED (2004) Glucose transport in the heart. Front Biosci 9:201-215

20. Richter EA, Hargreaves M (2013) Exercise, GLUT4, and skeletal muscle glucose uptake. Physiol Rev 93(3):993-1017. https://doi. org/10.1152/physrev.00038.2012

21. Jain SS, Chabowski A, Snook LA, Schwenk RW, Glatz JF, Luiken JJ, Bonen A (2009) Additive effects of insulin and muscle contraction on fatty acid transport and fatty acid transporters, FAT/CD36, FABPpm, FATP1, 4 and 6. FEBS Lett 583(13):2294-2300. https:// doi.org/10.1016/j.febslet.2009.06.020

22. Habets DD (2008) Thesis: "Regulation of cardiac long-chain fatty acid and glucose utilization. Studies with cardiomyocytes from genetically manipulated mice" Thesis Chapter 5: AICAR stimulates long-chain fatty acid uptake and oxidation in mouse heart independent of CD36

23. Thong FS, Bilan PJ, Klip A (2007) The Rab GTPase-activating protein AS160 integrates $\mathrm{Akt}$, protein kinase $\mathrm{C}$, and AMP-activated protein kinase signals regulating GLUT4 traffic. Diabetes 56(2):414-423. https://doi.org/10. 2337/db06-0900

24. Abbott MJ, Edelman AM, Turcotte LP (2009) CaMKK is an upstream signal of AMP-activated protein kinase in regulation of substrate metabolism in contracting skeletal muscle. Am J Physiol Regul Integr Comp Physiol 297(6):R1724-R1732. https://doi. org/10.1152/ajpregu.00179.2009

25. Habets DD, Coumans WA, El Hasnaoui M, Zarrinpashneh E, Bertrand L, Viollet B, Kiens B, Jensen TE, Richter EA, Bonen A, Glatz JF, Luiken JJ (2009) Crucial role for $\mathrm{LKB} 1$ to AMPKalpha2 axis in the regulation of CD36-mediated long-chain fatty acid uptake into cardiomyocytes. Biochim Biophys Acta 1791(3):212-219. https://doi.org/10. 1016/j.bbalip.2008.12.009

26. Samovski D, Su X, Xu Y, Abumrad NA, Stahl PD (2012) Insulin and AMPK regulate FA translocase/CD36 plasma membrane recruitment in cardiomyocytes via Rab GAP AS160 and Rab8a Rab GTPase. J Lipid Res 53 
(4):709-717. https://doi.org/10.1194/jlr. M023424

27. Luiken JJ, Glatz JF, Neumann D (2015) Cardiac contraction-induced GLUT4 translocation requires dual signaling input. Trends Endocrinol Metab 26(8):404-410. https:// doi.org/10.1016/j.tem.2015.06.002

28. Luiken JJ, Coort SL, Koonen DP, van der Horst DJ, Bonen A, Zorzano A, Glatz JF (2004) Regulation of cardiac long-chain fatty acid and glucose uptake by translocation of substrate transporters. Pflugers Arch 448 (1):1-15. https://doi.org/10.1007/s00424003-1199-4

29. Yamaguchi $S$, Katahira $H$, Ozawa $S$, Nakamichi Y, Tanaka T, Shimoyama T, Takahashi K, Yoshimoto K, Imaizumi MO, Nagamatsu S, Ishida H (2005) Activators of AMP-activated protein kinase enhance GLUT4 translocation and its glucose transport activity in 3T3-Ll adipocytes. Am J Physiol Endocrinol Metab 289(4):E643-E649. https://doi.org/10.1152/ajpendo.00456. 2004

30. Weisiger RA, Fitz JG, Scharschmidt BF (1989) Hepatic oleate uptake. Electrochemical driving forces in intact rat liver. J Clin Invest 83 (2):411-420. https://doi.org/10.1172/ JCI1 13899

31. Park KS, Jo I, Pak K, Bae SW, Rhim H, Suh SH, Park J, Zhu H, So I, Kim KW (2002) FCCP depolarizes plasma membrane potential by activating proton and $\mathrm{Na}+$ currents in bovine aortic endothelial cells. Pflugers Arch 443 (3):344-352. https://doi.org/10.1007/ s004240100703

32. Liu X, Chhipa RR, Pooya S, Wortman M, Yachyshin S, Chow LM, Kumar A, Zhou X, Sun Y, Quinn B, McPherson C, Warnick RE, Kendler A, Giri S, Poels J, Norga K, Viollet B, Grabowski GA, Dasgupta B (2014) Discrete mechanisms of $\mathrm{mTOR}$ and cell cycle regulation by AMPK agonists independent of AMPK. Proc Natl Acad Sci U S A 111(4): E435-E444. https://doi.org/10.1073/pnas. 1311121111

33. Bonen A, Han XX, Habets DD, Febbraio M, Glatz JF, Luiken JJ (2007) A null mutation in skeletal muscle FAT/CD36 reveals its essential role in insulin- and AICAR-stimulated fatty acid metabolism. Am J Physiol Endocrinol Metab 292(6):E1740-E1749. https://doi. org/10.1152/ajpendo.00579.2006

34. Russell RR 3rd, Bergeron R, Shulman GI, Young LH (1999) Translocation of myocardial GLUT-4 and increased glucose uptake through activation of AMPK by AICAR. Am J Phys 277 (2 Pt 2):H643-H649
35. Angin Y, Schwenk RW, Nergiz-Unal R, Hoebers N, Heemskerk JW, Kuijpers MJ, Coumans WA, van Zandvoort MA, Bonen A, Neumann D, Glatz JF, Luiken JJ (2014) Calcium signaling recruits substrate transporters GLUT4 and CD36 to the sarcolemma without increasing cardiac substrate uptake. Am J Physiol Endocrinol Metab 307(2): E225-E236. https://doi.org/10.1152/ ajpendo.00655.2013

36. Dirkx E, Schwenk RW, Coumans WA, Hoebers N, Angin Y, Viollet B, Bonen A, van Eys GJ, Glatz JF, Luiken JJ (2012) Protein kinase $\mathrm{Dl}$ is essential for contraction-induced glucose uptake but is not involved in fatty acid uptake into cardiomyocytes. J Biol Chem 287 (8):5871-5881. https://doi.org/10.1074/ jbc.M111.281881

37. Zhou G, Myers R, Li Y, Chen Y, Shen X, Fenyk-Melody J, Wu M, Ventre J, Doebber T, Fujii N, Musi N, Hirshman MF, Goodyear LJ, Moller DE (2001) Role of AMP-activated protein kinase in mechanism of metformin action. J Clin Invest 108(8):1167-1174. https://doi. org/10.1172/JCI13505

38. Musi N, Hirshman MF, Nygren J, Svanfeldt M, Bavenholm P, Rooyackers O, Zhou G, Williamson JM, Ljunqvist $\mathrm{O}$, Efendic $S$, Moller DE, Thorell A, Goodyear LJ (2002) Metformin increases AMP-activated protein kinase activity in skeletal muscle of subjects with type 2 diabetes. Diabetes 51(7):2074-2081

39. Yang J, Holman GD (2006) Long-term metformin treatment stimulates cardiomyocyte glucose transport through an AMP-activated protein kinase-dependent reduction in GLUT4 endocytosis. Endocrinology 147 (6):2728-2736. https://doi.org/10.1210/ en.2005-1433

40. Cool B, Zinker B, Chiou W, Kifle L, Cao N, Perham M, Dickinson R, Adler A, Gagne G, Iyengar R, Zhao G, Marsh K, Kym P, Jung P, Camp HS, Frevert E (2006) Identification and characterization of a small molecule AMPK activator that treats key components of type 2 diabetes and the metabolic syndrome. Cell Metab 3(6):403-416. https://doi.org/10. 1016/j.cmet.2006.05.005

41. Lai YC, Kviklyte S, Vertommen D, Lantier L, Foretz M, Viollet B, Hallen S, Rider $\mathrm{MH}$ (2014) A small-molecule benzimidazole derivative that potently activates AMPK to increase glucose transport in skeletal muscle: comparison with effects of contraction and other AMPK activators. Biochem J 460 (3):363-375. https://doi.org/10.1042/ BJ20131673 
42. Rajamohan F, Reyes AR, Frisbie RK, Hoth LR, Sahasrabudhe P, Magyar R, Landro JA, Withka JM, Caspers NL, Calabrese MF, Ward J, Kurumbail RG (2016) Probing the enzyme kinetics, allosteric modulation and activation of alphal- and alpha2-subunit-containing AMP-activated protein kinase (AMPK) heterotrimeric complexes by pharmacological and physiological activators. Biochem J 473 (5):581-592. https://doi.org/10.1042/ BJ20151051

43. Xiao B, Sanders MJ, Carmena D, Bright NJ, Haire LF, Underwood E, Patel BR, Heath RB, Walker PA, Hallen S, Giordanetto F, Martin SR, Carling D, Gamblin SJ (2013) Structural basis of AMPK regulation by small molecule activators. Nat Commun 4:3017. https://doi. org/10.1038/ncomms4017

44. Momken I, Chabowski A, Dirkx E, Nabben M, Jain SS, McFarlan JT, Glatz JF, Luiken JJ, Bonen A (2017) A new leptin-mediated mechanism for stimulating fatty acid oxidation: a pivotal role for sarcolemmal FAT/CD36. Biochem J 474(1):149-162. https://doi.org/10. 1042/BCJ20160804

45. Palanivel R, Eguchi M, Shuralyova I, Coe I, Sweeney G (2006) Distinct effects of shortand long-term leptin treatment on glucose and fatty acid uptake and metabolism in HL-1 cardiomyocytes. Metabolism $\quad 55$ (8):1067-1075. https://doi.org/10.1016/j. metabol.2006.03.020

46. Berti L, Gammeltoft S (1999) Leptin stimulates glucose uptake in $\mathrm{C} 2 \mathrm{C} 12$ muscle cells by activation of ERK2. Mol Cell Endocrinol 157 (1-2):121-130

47. Mu J, Brozinick JT Jr, Valladares O, Bucan M, Birnbaum MJ (2001) A role for AMP-activated protein kinase in contraction- and hypoxiaregulated glucose transport in skeletal muscle. Mol Cell 7(5):1085-1094

48. Samari HR, Seglen PO (1998) Inhibition of hepatocytic autophagy by adenosine, aminoimidazole-4-carboxamide riboside, and N6-mercaptopurine riboside. Evidence for involvement of amp-activated protein kinase. J Biol Chem 273(37):23758-23763

49. Musi N, Hayashi T, Fujii N, Hirshman MF, Witters LA, Goodyear LJ (2001) AMP-activated protein kinase activity and glucose uptake in rat skeletal muscle. Am J Physiol Endocrinol Metab 280(5):E677-E684

50. Henin N, Vincent MF, Van den Berghe G (1996) Stimulation of rat liver AMP-activated protein kinase by AMP analogues. Biochim Biophys Acta 1290(2):197-203

51. Iwatsubo K, Bravo C, Uechi M, Baljinnyam E, Nakamura T, Umemura M, Lai L, Gao S, Yan L, Zhao X, Park M, Qiu H, Okumura S, Iwatsubo M, Vatner DE, Vatner SF, Ishikawa Y (2012) Prevention of heart failure in mice by an antiviral agent that inhibits type 5 cardiac adenylyl cyclase. Am J Physiol Heart Circ Physiol 302(12):H2622-H2628. https://doi.org/10. 1152 /ajpheart.00190.2012

52. Niu W, Bilan PJ, Ishikura S, Schertzer JD, Contreras-Ferrat A, Fu Z, Liu J, Boguslavsky S, Foley KP, Liu Z, Li J, Chu G, Panakkezhum T, Lopaschuk GD, Lavandero S, Yao Z, Klip A (2010) Contraction-related stimuli regulate GLUT4 traffic in $\mathrm{C} 2 \mathrm{Cl2}$ GLUT4myc skeletal muscle cells. Am J Physiol Endocrinol Metab 298(5):E1058-E1071. https://doi.org/10.1152/ajpendo.00773. 2009

53. Merlin J, Evans BA, Csikasz RI, Bengtsson T, Summers RJ, Hutchinson DS (2010) The M3-muscarinic acetylcholine receptor stimulates glucose uptake in L6 skeletal muscle cells by a CaMKK-AMPK-dependent mechanism. Cell Signal 22(7):1104-1113. https://doi. org/10.1016/j.cellsig.2010.03.004

54. Vogt J, Traynor R, Sapkota GP (2011) The specificities of small molecule inhibitors of the TGFss and BMP pathways. Cell Signal 23 (11):1831-1842. https://doi.org/10.1016/j. cellsig.2011.06.019

55. Tokumitsu $\mathrm{H}$, Inuzuka $\mathrm{H}$, Ishikawa $\mathrm{Y}$, Ikeda M, Saji I, Kobayashi R (2002) STO-609, a specific inhibitor of the $\mathrm{Ca}(2+) /$ calmodulin-dependent protein kinase kinase. J Biol Chem 277(18):15813-15818. https:// doi.org/10.1074/jbc.M201075200

56. Witczak CA, Sharoff CG, Goodyear LJ (2008) AMP-activated protein kinase in skeletal muscle: from structure and localization to its role as a master regulator of cellular metabolism. Cell Mol Life Sci 65(23):3737-3755. https://doi. org/10.1007/s00018-008-8244-6 